\title{
Uji toksisitas akut limbah pengeboran minyak (serbuk bor) terhadap Artemia salina
}

\section{Acute toxicity test of oil drilling waste (drill cuttings) on Artemia salina}

\author{
E. Sriwahyuni ${ }^{*}$, M. Krisanti ${ }^{1}$ \\ ${ }^{1}$ Departemen Manajemen Sumberdaya Perairan, Fakultas Perikanan dan Ilmu Kelautan, IPB University, \\ Bogor, Indonesia
}

\begin{abstract}
Abstrak.
Penelitian ini bertujuan untuk mengetahui toksisitas akut limbah pengeboran eksplorasi minyak dan gas bumi berupa serbuk bor (cutting) pada brine shrimp (Artemia salina) dan pengaruhnya terhadap morfologi biota uji. Konsentrasi yang digunakan dalam uji toksisitas akut yaitu $22.000,39.000,70.000,126.000$ dan 226.000 ppm. Nilai konsentrasi akut (LC50) diperkirakan dengan menggunakan metode probit. Estimasi konsentrasi akut limbah serbuk bor (dril cutting) berupa LC50 96 jam adalah $34.260 \mathrm{ppm}$. Biota uji Artemia salina memberikan respons terhadap paparan limbah cutting, berupa perubahan pada posisi berenang, keaktifan biota uji, tingkat stres, serta kerusakan pada morfologi dan anatomi tubuh biota uji.
\end{abstract}

\begin{abstract}
This study aimed to determine acute toxicity of cutting as drilling waste of oil and gas exploration on brine shrimp (Artemia salina) and its influence on the morphology of the test biota. The concentration used in the acute toxicity test namely 22,000, 39,000, 70,000, 126,000 and 226,000 ppm. Acute concentration value (LC50) was estimated by probit methods. The concentration of acute toxicity (LC50) 96 hours of drilling cutting was 34,260 ppm. The test biota responded to exposure of cutting waste, in the form of changes in swimming position, activity, stress level and damage in the morphology and anatomy of the body.
\end{abstract}

Keywords: Artemia salina, cutting, LC50

Kata kunci: Artemia salina, limbah, LC50

\section{PENDAHULUAN}

Kegiatan pertambangan minyak dan gas mencakup beberapa tahap, yakni eksplorasi, eksploitasi, pemurnian dan pemasaran. Kegiatan ini juga menghasilkan limbah seperti produced water (air yang dipisahkan selama proses produksi minyak dan gas), lumpur bor bekas, serbuk bor (drill cutting), air panas dari proses pendinginan, minyak, asap pembakaran, sampah dan jenis limbah lainnya. Serbuk bor (drill cutting) merupakan hasil operasi pengeboran dari potongan lapisan bebatuan ketika mata bor menekan dan berputar di dalam perut bumi. Serbuk bor harus segera dikeluarkan dari sumur bor agar tidak mengganggu proses pengeboran. Pada prosesnya terjadi pencampuran antara material hasil pengeboran (serbuk bor, lumpur, pasir) dengan lumpur bor. Lumpur bor merupakan campuran air, lumpur khusus, beberapa mineral dan bahan kimia (EPA 1993). Hasil sampingan tersebut berpotensi toksik apabila tidak dilakukan pengolahan terlebih dahulu, sehingga dapat mencemari perairan sekitar anjungan di laut dan lokasi pemboran di darat (Mukhtasor 2007).

\footnotetext{
* Korespondensi Penulis

Email : endangsriwahy@gmail.com
} 
Dampak toksisitas limbah terhadap biota dapat timbul secara langsung dan tidak langsung. Dampak secara tidak langsung adalah terjadinya penurunan kualitas perairan (Kumar et al. 2013) yang dapat mengganggu kehidupan biota perairan. Biota perairan yang terganggu dapat berpengaruh terhadap keseimbangan ekosistem perairan. Oleh sebab itu, untuk mengetahui apakah limbah tersebut dapat mengganggu perairan maka diperlukan uji toksisitas akut.

Uji toksisitas merupakan uji yang digunakan untuk mengetahui efek negatif suatu zat terhadap biota. LC50 yaitu nilai konsentrasi pemaparan zat toksik yang menyebabkan 50\% biota uji mati (Moe et al. 2001). Uji toksisitas menggunakan makhluk hidup sebagai biota uji. Pemilihan biota uji didasarkan dengan kriteria biota uji yang harus dipenuhi berdasarkan Organization for Economic Cooperation and Development (OECD) dan US Environmental Protection Agency (US-EPA). Biota uji yang digunakan merupakan biota uji yang dapat mewakili kondisi lingkungan dari suatu perairan (APHA 2005 dalam DWMS 2007).

Biota uji pada penelitian ini adalah nauplius Artemia salina. Penggunaan Artemia salina sebagai biota uji laut bertujuan untuk mengetahui toksisitas akut serbuk bor (drill cutting) sebelum diperkenankan dibuang ke perairan laut. Artemia salina sangat baik digunakan sebagai organisme uji dalam uji toksisitas akut perairan laut karena sederhana dan akurat untuk semua jenis toksikan (Shaala et al. 2015). Organisme sederhana ini mudah dikultur dan dikembangbiakkan dalam kondisi laboratorium (Kanwar 2007). Berdasarkan hal tersebut, maka penelitian ini bertujuan menentukan nilai toksisitas akut limbah pengeboran minyak dan gas berupa serbuk bor terhadap Artemia salina, serta pengaruhnya terhadap morfologi biota uji.

\section{METODOLOGI}

\subsection{Lokasi kajian dan waktu penelitian}

Penelitian dilaksanakan pada bulan Februari hingga April 2016 di Laboratorium Riset Plankton, Departemen Manajemen Sumberdaya Perairan, Fakultas Perikanan dan Ilmu Kelautan, IPB University.

\subsection{Prosedur penelitian}

Nauplius merupakan anak Artemia yang baru menetas. Stadia ini merupakan stadia yang paling optimum untuk digunakan sebagai biota uji. Penelitian menggunakan 10 ekor Artemia salina terhadap 10 mL media uji di setiap konsentrasi percobaan. Air laut sebagai media diaerasi terlebih dahulu selama satu jam. Kista Artemia salina sebanyak $1 \mathrm{~g}$ dimasukkan ke dalam wadah penetasan yang berisi $1 \mathrm{~L}$ air laut. Kista menetas setelah sekitar 24 jam. Setelah kista menetas, dilakukan pemisahan cangkang kosong dengan nauplius. Setengah bagian atas wadah penetasan ditutup dengan plastik hitam agar tidak 
ada cahaya yang masuk, sedangkan setengah bagian bawah dibiarkan terbuka. Aerator dikeluarkan dari wadah penetasan. Nauplius berenang ke arah dengan intensitas cahaya lebih tinggi yakni ke bagian bawah wadah tetas, sehingga Nauplius dapat dengan mudah dialirkan keluar wadah melalui pipa konektor.

Limbah pengeboran yang dijadikan toksikan berupa serbuk bor (drill cutting) dalam bentuk supernatan. Supernatan merupakan bagian atas hasil pencampuran antara serbuk bor dengan akuades. Perbandingan antara bobot cutting (kg) dengan volume akuades (L) yakni 1:1. Proses pencampuran diasumsikan dapat melarutkan bahan toksik dari serbuk bor.

\subsection{Prosedur analisis data}

\subsubsection{Penentuan nilai ambang atas dan ambang bawah}

Uji pendahuluan dilakukan untuk mendapatkan selang konsentrasi serbuk bor yang digunakan pada uji toksisitas akut. Artemia salina yang digunakan berjumlah 10 ekor nauplius yang dipaparkan pada media toksikan bervolume 10 mL. Pada uji pendahuluan ditentukan konsentrasi ambang atas (N) dan konsentrasi ambang bawah (n). Nilai ambang atas dan ambang bawah digunakan untuk menentukan selang konsentrasi dalam uji toksisitas akut.

Konsentrasi ambang atas (N) merupakan konsentrasi terendah toksikan yang menyebabkan seluruh hewan uji mati pada pemaparan 24 jam. Konsentrasi ambang bawah (n) merupakan konsentrasi tertinggi toksikan yang tidak menyebabkan kematian hewan uji pada pemaparan 24 jam. Penentuan selang konsentrasi ditentukan dengan menggunakan Persamaan 1 dan Persamaan 2 (Koesoemadinata 1983).

$$
\begin{aligned}
& \log \frac{\mathrm{N}}{\mathrm{n}}=\mathrm{k} \log \frac{\mathrm{a}}{\mathrm{n}} . \\
& \frac{\mathrm{a}}{\mathrm{n}}=\frac{\mathrm{b}}{\mathrm{a}}=\frac{\mathrm{c}}{\mathrm{b}}=\frac{\mathrm{d}}{\mathrm{c}}=\frac{\mathrm{N}}{\mathrm{e}} .
\end{aligned}
$$

Keterangan :

$\begin{array}{ll}\mathrm{N} & : \text { Konsentrasi tertinggi } \\ \mathrm{n} & : \text { Konsentrasi terendah } \\ \mathrm{K} & : \text { Jumlah konsentrasi yang diuji } \\ \mathrm{a}, \mathrm{b}, \mathrm{c}, \mathrm{d} \text { dan e } & \text { Konsentrasi antara konsentrasi terendah dan konsentrasi tertinggi, a adalah } \\ & \text { konsentrasi terendah }\end{array}$

\subsubsection{Uji toksisitas akut}

Artemia salina yang dijadikan biota uji pada uji utama diusahakan memiliki ukuran yang seragam. Artemia salina dimasukkan ke dalam wadah uji yang berisi kontaminan sebanyak $10 \mathrm{~mL}$. Jumlah Artemia salina yang dipaparkan pada setiap perlakuan adalah 10 ekor. Perlakuan kontaminasi sebanyak lima buah dan satu buah perlakuan kontrol. 
Pada uji toksisitas diamati respons tingkah laku biota uji, kerusakan tubuh dan mortalitas. Pengamatan tingkah laku dilakukan berdasarkan geometrik seri yaitu pada pemaparan 0, 3, 6, 12, 24, 48, 72 dan 96 jam (Franson 1995). Pengamatan respons tingkah laku biota dilakukan dengan membandingkan tingkah laku biota pada kontrol dan perlakuan. Selama pemaparan juga dilakukan pengamatan kerusakan morfologi tubuh dan tingkat mortalitas. Kerusakan tubuh biota uji divisualisasi dengan mikroskop binokuler. Pengamatan mortalitas biota uji dilakukan secara visual dengan bantuan kaca pembesar.

Pendugaan nilai konsentrasi akut (LC50) menggunakan metode probit. Metode probit merupakan prosedur statistik parametrik pada selang kepercayaan 95\%. Analisis data dilakukan dengan software EPA Probit Analysis Program versi 1.5.

\section{HASIL DAN PEMBAHASAN}

\subsection{Uji pendahuluan dan uji toksisitas akut}

Uji pendahuluan dilakukan untuk menemukan nilai konsentrasi ambang atas dan ambang bawah. Tabel 1 merupakan beberapa hasil uji pendahuluan pada tiga kelompok konsentrasi yang berdekatan dengan kelompok konsentrasi ambang atas dan ambang bawah. Berdasarkan beberapa uji pendahuluan, didapatkan nilai ambang $(\mathrm{N})$ atas dan ambang bawah (n) masing-masing sebesar 200.000 ppm dan 12.500 ppm.

Tabel 1. Hasil uji pendahuluan.

\begin{tabular}{crc}
\hline \multicolumn{2}{c}{ Konsentrasi serbuk bor } & \multirow{2}{*}{ Mortalitas Artemia salina $(\%)$} \\
\cline { 1 - 2 }$(\%)$ & $(\mathrm{ppm})$ & 100 \\
20,00 & 200.000 & 80 \\
10,00 & 100.000 & 70 \\
5,00 & 50.000 & 50 \\
2,50 & 25.000 & 0 \\
1,25 & 12.500 & \\
\hline
\end{tabular}

Uji toksisitas akut dilakukan dengan pemaparan lima konsentrasi dan satu kontrol sebagai perlakuan terhadap 10 ekor nauplius Artemia salina. Konsentrasi yang digunakan dalam uji toksisitas akut ditentukan berdasarkan konsentrasi ambang atas dan ambang bawah. Lima konsentrasi tersebut adalah $22.000,39.000,70.000,126.000$ dan 226.000 ppm. Kematian biota uji pada uji utama terus meningkat dengan semakin tingginya konsentrasi dan lama pemaparan. Estimasi konsentrasi akut limbah diperoleh melalui analisis probit. Tabel 2 menunjukkan estimasi konsentrasi akut (LC50) cutting. 
Tabel 2. Estimasi nilai toksisitas akut (LC50) cutting.

\begin{tabular}{ccc}
\hline Exposure & EPA probit & Selang kepercayaan $95 \%$ \\
\hline 24 & 110.152 & $81.745-155.393$ \\
48 & 88.493 & $60.850-137.572$ \\
72 & 51.664 & $26.650-82.104$ \\
96 & 34.260 & $14.655-51.992$ \\
\hline
\end{tabular}

Nilai LC50 merupakan nilai yang menunjukkan besarnya konsentrasi suatu bahan uji yang dapat menyebabkan kematian 50\% hewan uji setelah 24 jam pemaparan. Brine Shrimp Test (BST) dianggap sebagai cara yang berguna untuk penilaian awal terhadap toksisitas karena sangat sederhana, murah dan sensitif (Jegathambigai et al. 2014). Konsentrasi akut yang mematikan 50\% hewan uji pada studi ini sebesar 34.260 ppm. Menurut PerMenESDM Nomor 45 Tahun 2006 tentang Pengelolaan Lumpur Bor dan Serbuk Bor pada Kegiatan Pengeboran Minyak dan Gas Bumi, nilai batas LC50-96 jam limbah yang dapat dibuang ke laut adalah $\geq 30.000 \mathrm{ppm}$. Berdasarkan peraturan tersebut, limbah yang diamati pada studi ini dapat dibuang langsung ke laut, namun harus memperhatikan lingkungan sensitif di sekitarnya dan harus mengantongi izin pembuangan dari pemerintah.

\subsection{Tingkah laku dan kerusakan morfologi nauplius}

Nauplius Artemia sering digunakan untuk evaluasi toksisitas bahan pencemar dan studi ekotoksikologi (Manzanares et al. 2015). Biota uji menunjukkan respons terhadap limbah berupa tingkah laku selama uji toksisitas. Tingkah laku yang ditunjukkan meliputi keaktifan pergerakan, posisi berenang, tingkat stres dan perubahan tingkah laku lainnya. Tingkah laku biota uji sangat beragam berdasarkan tingkat konsentrasi yang dipaparkan. Semakin tinggi konsentrasi dan lama pemaparan, maka biota uji semakin stres hingga terjadi kematian. Data kematian pada toksisitas Artemia dapat dikaitkan dengan sifat toksik dari bahan uji (Hartl and Humpf 2000). Respons yang ditunjukkan biota sudah terlihat pada awal waktu pemaparan. Respons tingkah laku biota uji sangat terlihat pada konsentrasi tertinggi perlakuan yakni 226.000 ppm. Respons biota uji secara keseluruhan adalah berupa stres yang terlihat dari cara berenang yang sangat cepat tak beraturan di kolom air. Hari kedua dan selanjutnya terlihat pergerakan biota uji sangat lemah. Hal ini diduga karena energi yang sudah banyak dipakai pada hari pertama pemaparan. Posisi berenang biota uji pada hari-hari selanjutnya cenderung ke arah dasar atau permukaan air. Pada jam ke 72 dan ke 96, terlihat banyak biota uji yang pingsan. Biota uji dikatakan pingsan karena biota uji terlihat mati tidak bergerak, namun biota uji kembali bergerak setelah diberi suatu aksi sentuhan. 
Biota uji yang terpapar serbuk bor tidak hanya merespons dengan perubahan tingkah laku, namun juga dengan timbulnya kerusakan bentuk morfologi tubuh berdasarkan lama pemaparan sebelum akhirnya mati. Kerusakan bentuk morfologi dapat diketahui dengan perbandingan morfologi tubuh Artemia salina kontrol dengan perlakuan serbuk bor. Ilustrasi kerusakan morfologi tubuh nauplius hanya dilakukan pada konsentrasi 39.000 ppm karena kerusakannya terlihat paling mencolok dan konsentrasi tersebut mendekati konsentrasi akut LC50. Hasil dokumentasi pada konsentrasi lain tidak memberikan gambaran yang cukup jelas.

Artemia salina mengalami kerusakan secara bertahap mulai dari bagian dalam tubuh hingga ke bagian luar (Gambar 1). Biota uji yang mati akibat pemaparan selama 24 jam memperlihatkan bentuk kerusakan pada bagian kepala, sedangkan pemaparan selama 48 jam menyebabkan kecenderungan rusak pada bagian dalam tubuh, khususnya bagian pencernaan. Pemaparan selama 72 jam menyebabkan kerusakan pada bagian dalam tubuh biota uji, sedangkan kerusakan total dalam dan luar tubuh biota uji terjadi pada pemaparan 96 jam. Kerusakan bagian dalam dan luar tubuh, serta kematian pada Artemia salina yang terkena paparan limbah yang memiliki kandungan logam berat dapat menyebabkan penghambatan pada pertumbuhan dan perkembangannya (Shaojie and Wenli 2012). Pada penelitian dengan biota uji post larva Penaeus monodon, kematian biota uji yang terpapar drilling muds disebabkan oleh kerusakan bentuk gill filamen berupa reduksi atau hilangnya bagian tubuh (Soegianto et al. 2008).

Tubuh Artemia salina terdiri dari kepala, toraks dan perut (Dumitrascu 2011). Kerusakan tubuh biota uji secara bertahap terjadi berdasarkan lama pemaparan. Tahapan kerusakan terjadi pada bagian kepala (mulut, mata, dsb.), saluran pencernaan, kerusakan total seluruh bagian dalam tubuh biota, lalu kerusakan total bentuk tubuh biota uji. Tahapan kerusakan tubuh ini menunjukkan bahwa kerusakan terjadi berdasarkan tingkat interaksi terendah hingga tertinggi antara organ tubuh biota dengan bahan toksik. Artemia sp. memiliki cara makan non selektif filter yang membuatnya rentan terhadap bahan pencemar yang masuk dalam badan perairan. Hal tersebut menyebabkan bagian kepala mengalami kerusakan terlebih dahulu.

Toksisitas merupakan kemampuan suatu molekul atau senyawa kimia untuk menimbulkan kerusakan pada bagian yang sensitif di dalam maupun di luar tubuh makhluk hidup. Suatu senyawa kimia dapat dikatakan sebagai racun apabila ketika senyawa tersebut bereaksi dengan satu objek dapat menimbulkan efek yang merusak (Durham 1975). Efek toksik yang dihasilkan memberikan indikasi terganggunya proses morfologi maupun fisiologis biota uji (Anderson et al. 1991), dalam hal ini bentuk morfologi tubuh Artemia sebagai biota uji. 


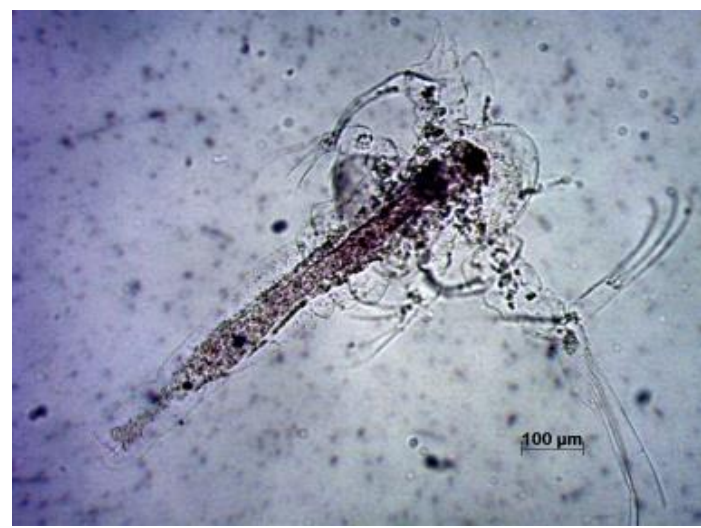

(a)

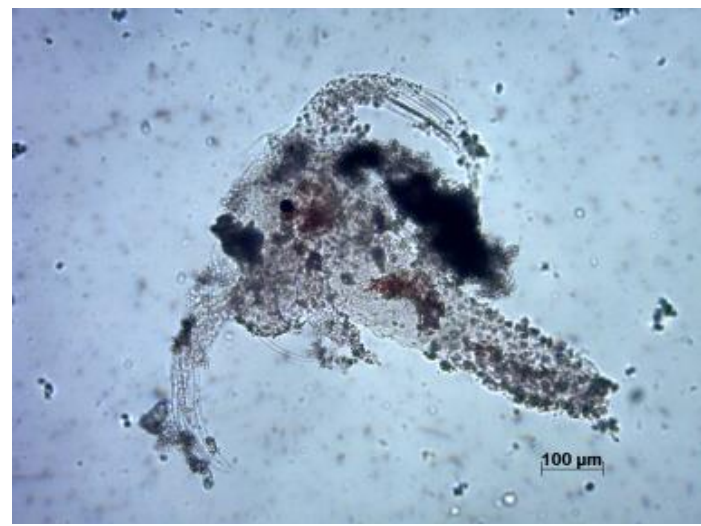

(c)

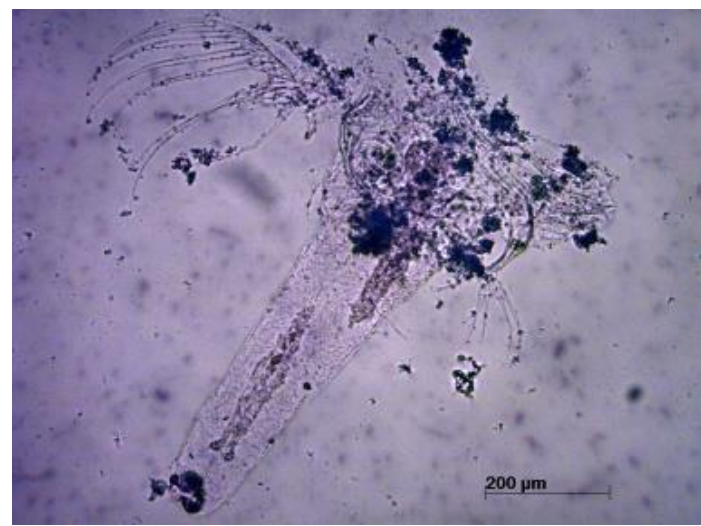

(b)

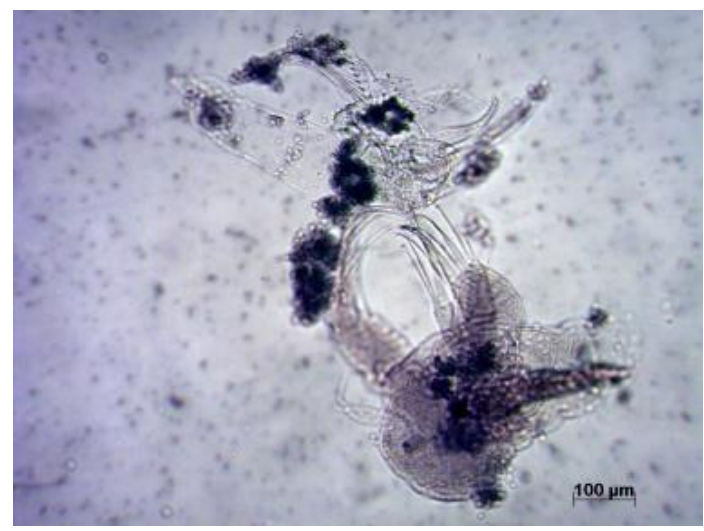

(d)

Gambar 1. Kerusakan morfologi biota uji pada pemaparan serbuk bor 39.000 ppm. (a) jam ke-24, (b) jam ke-48, (c) jam ke-72, (d) jam ke-96

Kecenderungan kerusakan bagian kepala (antena dan antenula) terlebih dahulu pada jam ke 24 diduga karena antena banyak menyaring limbah. Antena berfungsi sebagai filter feeder, sehingga kondisi lingkungan yang terpapar limbah menyebabkan Artemia sangat intensif berinteraksi dalam menyaring limbah. Berdasarkan Gambar 1, kerusakan biota uji yang terpapar limbah selama 48 jam mengalami kerusakan pada saluran pencernaan. Hal ini diduga karena serbuk bor yang masuk mulai bereaksi toksik pada bagian dalam tubuh biota, khususnya saluran pencernaan. Hal ini didukung dengan pernyataan Shaojie and Wenli (2012) yang menyatakan bahwa Artemia sp. dianggap sebagai organisme yang paling baik untuk uji toksisitas karena Artemia memiliki cara makan non selektif filter yang membuat mereka rentan terhadap bahan pencemar yang masuk dalam badan perairan. Kerusakan biota uji yang terpapar limbah selama 72 hingga 96 jam mengalami kerusakan total pada bagian dalam tubuh hingga bentuk luar tubuh biota uji. 
Tingkah laku biota uji yang bertahan hidup dalam paparan limbah memberikan respons yang sinergis dengan tingkat konsentrasi. Sesuai dengan pernyataan Loomis (1978), efek yang ditimbulkan oleh senyawa beracun sangat bergantung pada kadar racun yang diberikan. Dengan demikian, kematian biota uji terhadap pemaparan serbuk bor diduga diakibatkan oleh bahan kimia yang terkandung dalam limbah pengeboran. Meskipun menurut PerMenESDM Nomor 45 Tahun 2006 tingkat toksisitas serbuk bor masih memenuhi baku mutu, namun kerusakan tubuh hingga kematian pada biota uji selama pengamatan perlu menjadi pertimbangan dan perlu dilakukan pengkajian lanjutan mengenai volume limbah yang aman terhadap suatu luasan badan tampung limbah.

\section{KESIMPULAN DAN SARAN}

Konsentrasi toksisitas akut (LC50) serbuk bor adalah 34.260 ppm. Pengaruh limbah pengeboran migas berupa serbuk bor terhadap brine shrimp (Artemia salina) yakni terjadinya kerusakan pada seluruh morfologi dan anatomi tubuh biota uji secara bertahap berdasarkan lamanya pemaparan. Berdasarkan kerusakan tubuh yang mulai terjadi pada konsentrasi terendah uji utama, maka perlu dilakukan uji toksisitas kronik limbah pengeboran. Diperlukan uji toksisitas menggunakan organisme bentik perairan dengan tujuan untuk mengetahui pengaruh limbah terhadap organisme dasar dan sedimen perairan.

\section{UCAPAN TERIMAKASIH}

Penelitian ini didukung oleh Pusat Penelitian Lingkungan Hidup (PPLH) IPB University.

\section{DAFTAR PUSTAKA}

Anderson JE, Goetz CM and McLaughlin JL. 1991. A blind comparison of simple bench-top bioassay and human tumor cell cytotoxicities as antitumor prescrenss. Phytochemical Analysis Journal 2(1):107-111.

Dumitrascu M. 2011. Artemia salina. Balneo-Research Journal 2(4):119-122.

Durham WF. 1975. Toxicity. In: Sax NI. 1975. Dangerous properties of industrial materials, 4th ed. Van Nostrand Reinhold Co. New York.

[DWMS] Drilling Waste Management System. 2007. Drilling waste management information system [internet]. Tersedia di: http://web.ead.anl.gov/dwm/ techdesc/index.cfm.

[EPA] Environmental Protection Agency. 1993. Development document for effluent limitation guidelines and new source performance standards for offshore subcategory of the oil and gas extraction point source category. EPA. Washington DC. 
Franson MAH. 1995. Standard methods: for the examination of water and wastewater, 19th ed. APHA. Washington DC.

Hartl $\mathrm{M}$ and Humpf HU. 2000. Toxicity assessment of fumonisins using the brine shrimp (Artemia salina) bioassay. Food and Chemical Toxicology 28(2000):1097-1102.

Jegathambigai R, Rusli I and Sreenivasan S. 2014. Acute oral toxicity and brine shrimp lethality of methanol extract of Mentha spicata L (Lamiaceae). Tropical Journal of Pharmaceutical Research 13(1):101-107.

Kanwar AS. 2007. Brine shrimp as a marine animal for simple and rapid biological assays. Journal of Chinese Clinical Medicine 2(4):236-240.

Koesoemadinata S. 1983. Pedoman umum pengujian laboratorium toksisitas lethal pestisida pada ikan untuk keperluan pendaftaran komisi pestisida. Departemen Pertanian. Jakarta.

Kumar RT, Sampson AL, Dorathy E, Wokoma I and Ablorh MA. 2013. Study on environmental impact on oil and gas activities in Ghana - analysis by graphical approaches using matlab. International Journal of Engineering Trends and Technology 4(3):344-348.

Loomis TA. 1978. Toksikologi dasar, edisi III. Ed. Donatus IA. Semarang Pr. Semarang.

Manzanares DL, Morilla LJG, Malawani AD, Lagare NJS and Abrenica-Adamat LR. 2015. Effects of oregano (Origanum vulgare) leaf extract on early life stages of Artemia salina. International Journal of the Bioflux Society 7(3):468-474.

Moe J, Stenseth NC and Smith R. 2001. Effects of a toxicant on population growth rates: sublethal and delayed responses in blowfly populations. International Journal of Functional Ecology 15:712-721.

Mukhtasor. 2007. Pencemaran pesisir dan laut. Paradya Paramita. Jakarta.

PerMenESDM (Peraturan Menteri Energi dan Sumberdaya Mineral) Nomor 45 Tahun 2006 tentang pengelolaan lumpur bor dan serbuk bor pada kegiatan pengeboran minyak dan gas bumi.

Shaala NMA, Zulkifli SZ, Ismail A, Azmai MNA and Mohamat-Yusuff F. 2015. Selected morphological changes in nauplii of brine shrimp (Artemia salina) after tributyltin chloride (TBTCL) exposure. World Applied Sciences Journal 33(8):1334-1340.

Shaojie DZ and Wenli. 2012. Responses of growth and development of Artemia salin to four kinds of heavy metals stress. Procedia Environmental Sciences 12(2012):1164-1171.

Soegianto A, Irawan B and Affandi M. 2008. Toxicity of drilling waste and its impact on gill structure of post larvae of tiger prawn (Penaeus monodon). Global Journal of Environmental Research 2(1):36-41. 